\title{
Symbolic Representation of Tun Dr Mahathir: Visual Analysis of a Malaysian Short Film
}

\author{
UMA RANI A RETHINA VELU \\ Faculty of Languages and Linguistics, \\ University of Malaya \\ alum_vc@yahoo.com \\ CHERISH HOW \\ Faculty of Languages and Linguistics, \\ University of Malaya
}

\begin{abstract}
The fragmented frames of a short film which comprise still images and signs can be visually explored in the representation of timing. The significance of such a visual representation can lead to the formation of synchronised discursive structures that reflect upon political and social time summons in the past, present and future. The issue is that the political and social agendas mapped with ideas of a pre-election campaign and synchronised with time summons may indirectly provoke viewers' perception of a social actor through semiotic implications. Using a single component framework consisting of Kress and van Leeuwen's (2006) grammar of visual design, representational and viewer network and Hall's (2006) reception theory, this study explores the way agency is targeted visually towards the idea of a political change with pre-election sentiments of a prime minister. On one hand, through the choice of images Tun Dr Mahathir's past political successes are symbolically represented. On the other hand, he is signified with message of 'hope' for a better future to his country and nation.
\end{abstract}

Keywords: political discourse; short film; symbolic roadmaps; timing; visual representation

\section{VISUAL ANALYSIS OF A SHORT FILM}

The analysis of images within fragmented still frames of a short film can give way to various symbolic demands signified through the film's images and signs. The images of social actors may represent a particular person or persons; while signs commonly known as mise-en-scene which refers to any objects or things in filming technique may enhance meaning making of real life situations (van Leeuwen, 2008). Therefore, images or signs by suggestion and connotation through media's context such as that of a short film may appeal to the conscious of the viewers. Such an appeal at times may bring to light half-forgotten knowledge (Berger, 1972).

Any historical knowledge of the past with relevance to the composition of social actors and filmic technique may signify symbolically with present times through viewers' perception (van Leeuwen, 2008). Furthermore, when images or signs are decoded by the viewers through social distance, interaction and relation, any form of hidden agendas may be negotiated visually to fulfil certain political or social agendas. The agendas depend upon what is visually accepted, dismissed or denied by the encoded messages through filmic representations by the viewers.

The signification of images in films when interpreted through different readings provides grammar of visual design in the formation of various conceptual notions (van Leeuwen, 2008) leading to "conceptual leaps" (MacDougall, 2005, p. 233). Short films with various semiotic provocation broadcast within a short space of time have the tendency to restructure viewers' perception in order to communicate symbolically depending on whom the film visually intends 
to convey the messages through its multimodal representation (Kress, 2004; Bezemer \& Kress, 2008).

The visual representation in a short film with Malaysian Prime Minister Tun Dr Mahathir having one of the leading roles is significant as the film is used as a tool for his pre-election political campaign to win the hearts of Malaysian of all ages and walks of life. It is also significant as the past and present ideas of his political career are visually embedded through the images and signs of the film narrative. Such intentions could be visually designed to either socially associate the Malaysian society or his past and present political return with a symbol of 'hope' to free the country from the reigning regime. Overall, this study is significant as on the $9^{\text {th }}$ of May 2018, through the choice of the Malaysian people, Tun Dr Mahathir once again returned to politics to reign as the prime minister of Malaysia. Hence, the visuals in the short film of Tun Dr Mahathir played a vital role as his inclusion as the main actor signified him as symbol of hope, politically for a better future brought victory to him and his party in the $9^{\text {th }}$ May 2018 election. At the same time, the visual signs in HARAPAN symbolically brought awareness among Malaysians to the change of government after 60 years reign of Barisan Nasional (BN).

Studies on the analysis of visual representation on short films are rather scarce. From a Malaysian perspective, Khoo (2008) analysed the social-cultural geographical urban landscapes of the capital city of Malaysia, Kuala Lumpur. Khoo's (2008) focus was on alternative imagery and sociocultural mappings in three films. Findings showed the films gave preference to nongovernmental communities as pretexts to politicise the national landscape via ethnicity and race politics. Khoo's (2008) study is similar to our study on short film that consists of several landscapes such as the state of Kedah, city of Kuala Lumpur and Putrajaya based on Malaysian socio-cultural aspect. Besides, from a non-Malaysian perspective, Sora (2010) did a study based on the phenomenology of time that explains how the representation of time provides visual interpretation through interactive images as well as interactive application. Furthermore, Coëgnaerts and Kravanja (2012) analysed various films by using multimodal and visual examples. Their findings relate to the use of spatial time from a metaphorical perspective via non-verbal form of communication. Both studies from a global aspect are similar to our study from a visual aspect based on the concept of time but not in short film produced in Malaysia. Izharuddin (2015) analysed the short film of Mien Ly from a Malaysian perspective. Izharuddin gave preference to the articulation of feminist queer theory and not on a political leader in reference to the representation on time. Additionally, Perry (2018) examined the development of the $21^{\text {st }}$ century skills via short film production in tertiary education level at Universiti Kebangsaan Malaysia. However, her aim was on examining how short film production assists students in developing learning process and not on visual analysis. In addition, A Rethina Velu and Kaur (2018a, 2018b) analysed the visuals of a Malaysian televised show with focus on the representation of masculinity. Thus, their study gave focus to visual interpretation in an educational sitcom in regards to gender instead of a short film. Apart from that, Abas and Kaur (2019) study is comparable with our study as they give emphasis on the word 'faith' while ours is on the word 'hope'. However, their study was on football in The Star, Malaysian news articles, instead of a short film. Compared to all these existing studies concerning visuals, time in film analysis, our study fulfils the gap by contributing to the visual analysis of time summons involving a prime minister in a short film. 


\section{SHORT FILM: HARAPAN}

A short film entitled HARAPAN (hope) was broadcast on Tun Dr Mahathir's official Facebook page and YouTube website (Lemiere, 2018) on the $28^{\text {th }}$ of April 2018 (Vega, 2018), two weeks before the $14^{\text {th }}$ Malaysian General Election campaign. The duration of the film is 10 minutes and 28 seconds. A shorter version of the video with duration of 2 minutes and 20 seconds was also shared on Tun Dr Mahathir's official Twitter page on the $27^{\text {th }}$ of April 2018. It was reported that both full and shorter versions of the film have been viewed 250,000 times by viewers within the first 30 hours since it was uploaded on media (Vega, 2018).

The settings of the short film involve scenes from the state of Kedah, the city of Kuala Lumpur and the art gallery of Prime Ministers in Putrajaya in Malaysia. This film consists of two main characters who are Tun Dr Mahathir and a girl named Aisyah along with four minor characters, her grandfather, grandmother, father and brother. The narrative is based on Aisyah who lives with her grandparents in a village in the state of Kedah. She shows interest in Tun Dr Mahathir and his development of Malaysia by being inquisitive about him. She visits her father and brother who live in Kuala Lumpur where they struggle to make a living. Next, Aisyah is seen in a Malaysian car travelling to Kuala Lumpur in order to visit the prime ministers' art gallery at Putrajaya. Surprisingly, Aisyah comes face to face with Tun Dr Mahathir at the art gallery where they have a conversation with each other. The film ends with the car heading back to Aisyah's hometown. The title HARAPAN (hope) appears at the end of the last scene.

\section{POLITICAL REIGN OF A PRIME MINISTER}

Tun Dr Mahathir, as the Prime Minister of Malaysia from 1990 till 2002 under Barisan Nasional $(\mathrm{BN})$ or National Front, brought vast changes in modernising Malaysia. The construction of Petronas Twin Towers built in the heart of Kuala Lumpur began with his initiation to put Malaysia on the world map as the first country with the first tallest twin towers (Song \& Sivachandralingam Sundara Raja, 2018). While Malaysia opened doors to the world through the attraction of Petronas Twin Towers, Putrajaya was developed and recognised as the new capital city (Milne \& Mauzy, 2002).

Additionally, Petronas, the first petroleum industry, became recognisable worldwide. Apart from making Malaysia famous with the identity of Petronas, he further initiated the first Formula One race at the Sepang circuit (Milne \& Mauzy, 2002). With new built circuit designed to accommodate the world's famous car race, Tun Dr Mahathir also successfully introduced the first Malaysian car, Proton Saga (Milne \& Mauzy, 2002). Together with it came by the local automobile industries that provided jobs for Malaysians, opening the doors to local car industry such as Proton and Edaran Otomobil Nasional (EON). Due to these contributions, Tun Dr Mahathir has been honoured as the "Father of Modernisation" by the Malaysians (Vijayan Munusamy, 2012, p. 126).

The most intriguing part of Tun Dr Mahathir's reign was him introducing Vision 2020 to the nation. By the year 2020, he idealised Malaysia to be an independent prosperous nation on its own and free from any form of corruption. His ideal vision was probably to have those given scholarships to advance themselves with merit in education to return and serve the nation in every job sector towards achieving his vision of an independent successful nation (Milne \& Mauzy, 2002). However, his vision came with a price. Corruption among his own political party 
members was beyond his control and of which he did not tolerate (Ng \& Zainal Amin Ayub, 2018).

In 2003, Tun Dr Mahathir declared his resignation as president of BN party. His resignation also marked the end of his term as the Prime Minister of Malaysia. Interestingly, Tun Dr Mahathir was given the privilege to nominate Tun Abdullah Badawi for the BN presidency and as the $5^{\text {th }}$ Prime Minister of Malaysia (Vijayan Munusamy, 2012). After six years of Tun Abdullah Badawi's rule, Najib Razak became the $6^{\text {th }}$ prime minister in 2009. During Najib's eight years reign, cost of living and prices of properties boomed tremendously, burdening the people. Malaysians who were enjoying simple inexpensive lifestyle began to feel the pinch due to financial and economic crisis across the country. Though previously devoted to BN, Tun Dr Mahathir formed a new party Parti Pribumi Bersatu Malaysia (PPBM) with his followers from BN. Later, PPBM with other opposition parties formed Pakatan Harapan (PH) with the hope and promise to prevent corruption under Najib Razak's reign (Ng \& Zainal Amin Ayub, 2018). At the age of 93, Tun Dr Mahathir for the second time was elected as the Prime Minister of Malaysia. Not only was he the oldest prime minister to Malaysians, but also in the world (Gee, 2018).

\section{THE RETURN OF A PRIME MINISTER}

The $14^{\text {th }}$ general election in Malaysia was held on the $9^{\text {th }}$ of May 2018. This election took place as Najib Razak dissolved the $13^{\text {th }}$ elected parliament on the $17^{\text {th }}$ of April 2018. Najib Razak's ruling party known as Barisan Nasional (BN) was defeated by Pakatan Harapan (PH) through an unprecedented victory led by Tun Dr Mahathir who joined opposition coalition against BN (Walid Jumblatt Abdullah, 2018). In this election, out of 222 parliamentary seats, 121 seats had won by PH thus allowing Tun Dr Mahathir to return as the next prime minister of Malaysia for the second time. At the same time, his return was no more as a member of BN party that had ruled Malaysia since the independence from British rule in 1957. Interestingly, BN formerly known as Alliance Party had been the ruling party for sixty years in Malaysia. The end of BN as ruling party of Malaysia through the $14^{\text {th }}$ election in 2018 also marked Najib Razak as the last Prime Minister of Malaysia from BN (Ting, 2009). With the end of BN rule, Tun Dr Mahathir was sworn in as the $7^{\text {th }}$ Prime Minister of Malaysia on the $10^{\text {th }}$ of May 2018.

\section{DATA AND METHODOLOGY}

In this article, we examine how Tun Dr Mahathir is represented in the short film HARAPAN before the $14^{\text {th }}$ Malaysian general election. Specifically, we intend to answer the following research questions:

1. How do the still images and signs of the short film HARAPAN visually represent different political notions of timing of a prime minister?

2. How do the still images and signs of the short film HARAPAN visually reflect pre-election sentiments from a social perspective of a prime minister?

In the following sections, we present how the data are examined in the form of still images and signs in the short film. We also explain the procedure involved in our analysis together with outcomes of the findings communicated visually through this film. The final part of this article concludes with recommendations for future studies. 
The data in this study derive from the short film HARAPAN downloaded from YouTube website. With the historical knowledge of Tun Dr Mahathir's political status, we viewed the film several times. Specifically, we examined the prominence given to the representation of Tun Dr Mahathir's depiction with other actors through his images within a frame of the film with other actors.

The frames as mentioned in this study relates to camera shots in the form of stills. The stills of images and signs assist us to explore different fragments of time summons from a visual perspective (van Leeuwen, 2008). We also examined mise-en-scene elements which consist of objects or any other symbolic elements apart from the actors within a frame throughout the short film. Importantly, the signs visually contributed to various ideas in relation to political and social sentiments in regards to Tun Dr Mahathir's return to politics in terms of different political timing that relates the past, present and future.

After exploring HARAPAN from beginning till the end, a total of 20 frames were identified as symbolically meaningful with agency given both politically and socially to Tun Dr Mahathir together with other character roles. These 20 frames were recorded in the form of stills. These stills that followed the flow of the short film from beginning till the end reflect the past, present, and future political and social ideas in reference to Tun Dr Mahathir. Apart from that, Aisyah plays a dominant character role by leading the narrative in the film with ideas into various compositions with social 'timing' and mise-en-scene that relates to Tun Dr Mahathir.

Figure 1 shows the twenty identified still frames which are all in accordance to the film narrative flow from beginning till the end.

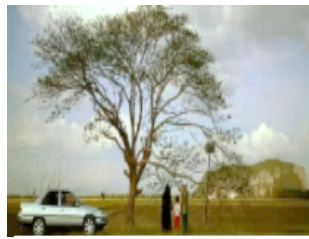

Frame 1

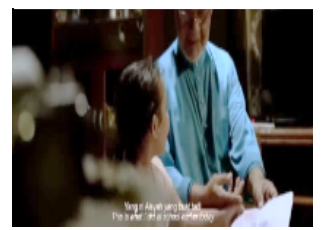

Frame 6

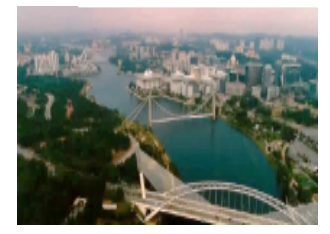

Frame 11

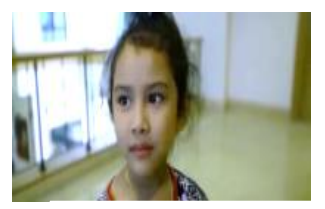

Frame 16

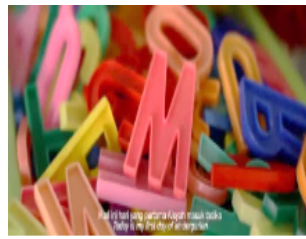

Frame 2

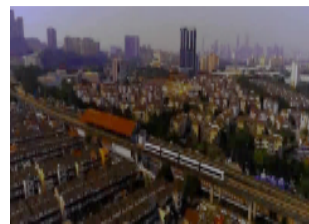

Frame 7

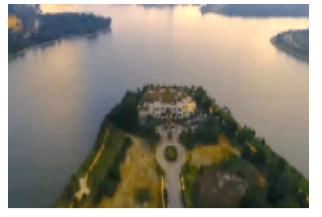

Frame 12

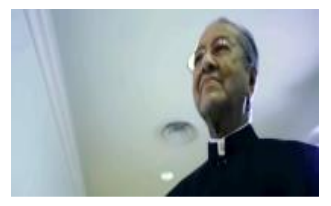

Frame 17

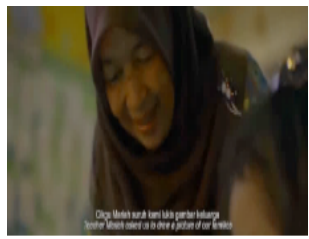

Frame 3

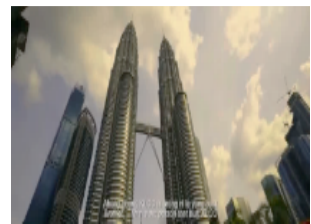

Frame 8

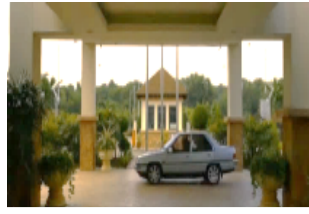

Frame 13

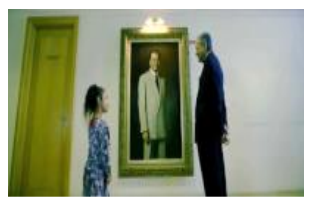

Frame 18

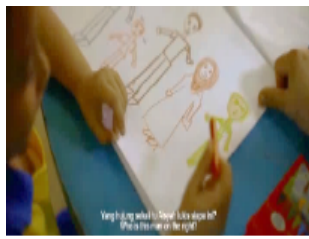

Frame 4

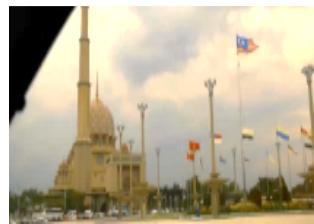

Frame 9

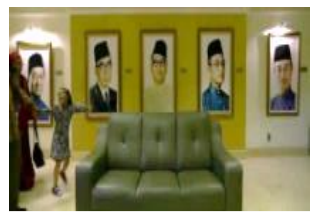

Frame 14

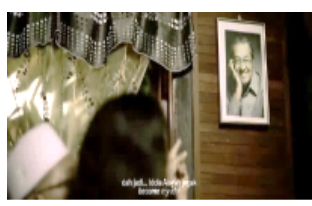

Frame 19

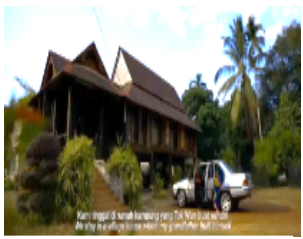

Frame 5

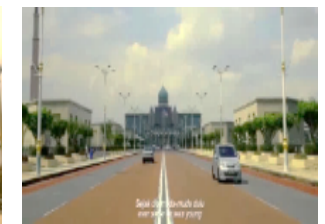

Frame 10

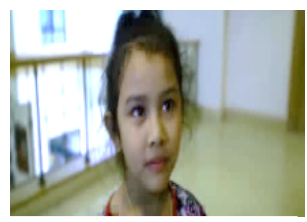

Frame 15

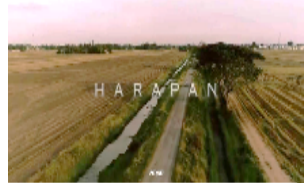

Frame 20

FIGURE 1. Identified frames 
These twenty still frames were identified as data and coded as Frame 1 to Frame 20 for the purpose of analysis in order to answer the two research questions in this study: the notion of timing with political notion and social sentiments in the visual representation of Tun Dr Mahathir. As the objective of this study is to visually analyse the images and signs of the short film, we decided not to include the subtitles and any form of spoken dialogue between Tun Dr Mahathir and Aisyah. Hence, the word HARAPAN (hope) as it appears on scene at the end of the film (Frame 20) is analysed from a grammatical visual perspective designed with the notion of timing (van Leeuwen, 2008).

\section{FRAMEWORK FOR ANALYSIS}

The theoretical underpinning in this study is in the form of a single component framework consisting of three different compositions which was specifically designed for this study to assist us in the analysis of HARAPAN. The framework design is shown in Figure 2.

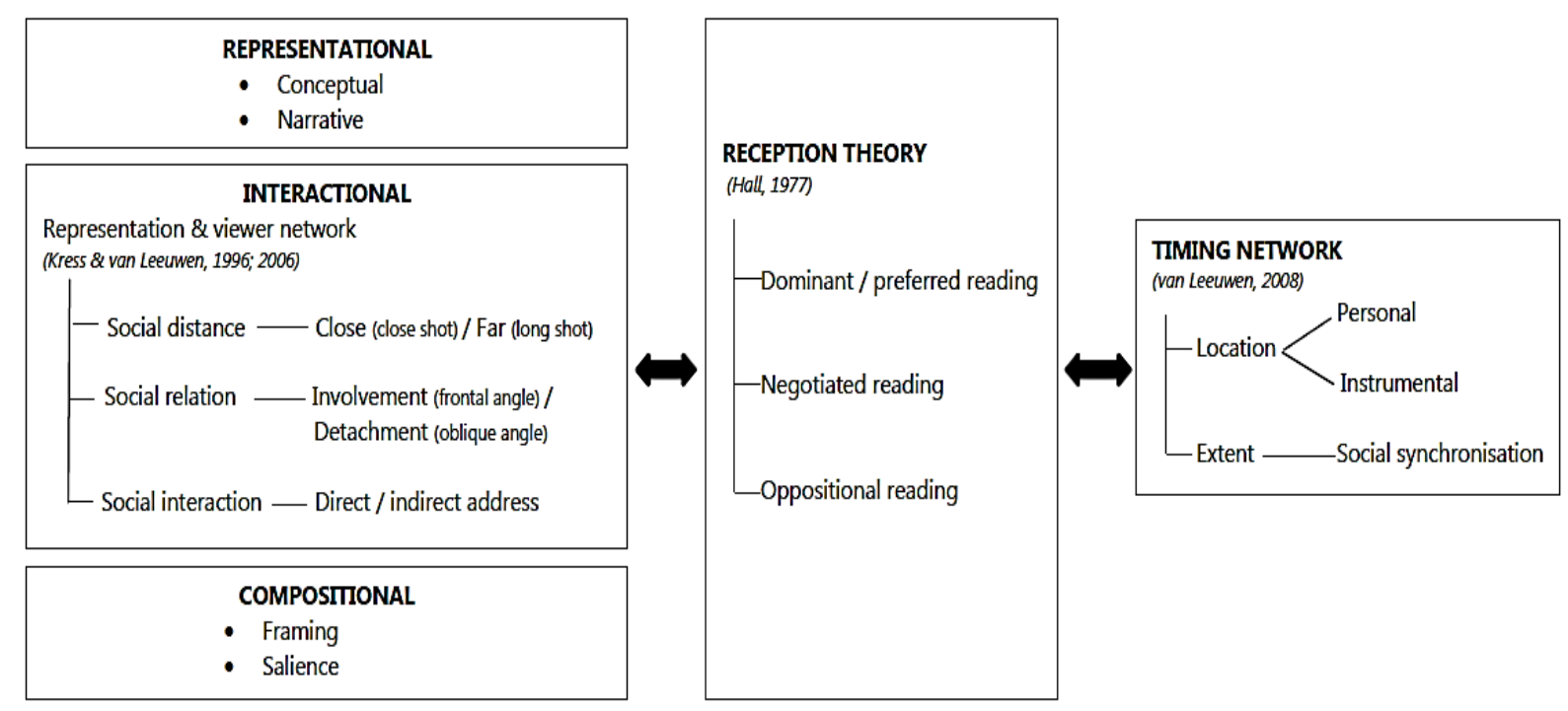

FIGURE 2. Single component framework design for analysis

Firstly, the symbolic meaning making of images and signs within each individual selected still frame was analysed using different functions. The functions are of representational, interactional and compositional meaning making (Kress \& van Leeuwen, 2006) from viewers' perspective.

Representational allows us to explore the ideas and concepts that lead to various roadmaps such as patterns of timing embedded with political and social timing across the overall narrative of the short film. The analysis also involves Hall's (2006) idea where process of representation is considered as a form of mediation that constitutes the very world it intends to represent or communicate with. To do so, Hall (2006) suggests that images and signs can give way to conceptual meanings to the world besides reflecting it. In other words, meaning making through the very images and signs of a particular culture can be traced as to how particular images and signs are reflected depending on media's dynamic work that visually shapes viewers' perception towards an idea centralised with symbolic relationships. In this study, the symbolic relationship is of political and social sentiments towards a prime minister. 
Secondly, we adopt van Leeuwen's (2008) representation and viewer network to analyse interactional meaning making with symbolic visual demand from the actor and the viewer. This network can assist us in examining the semiotic divisions from a social perspective of images that visually depict social distance, social interaction and social relation that of technical input. These dimensions need to be examined in order to provide a three dimensional aspects of analysis of how a person is portrayed by suggestion or connotation from a historical perspective visually with symbolic demands. Symbolically, the demands can be from images of people within cinematic distant, angle and gaze (Mulvey, 1975). Such demands can convey ideas with awareness to viewers with meaningful real life situation as in this study from political and social perspective.

Therefore, representation and viewer network allows us to examine visual representation based on still images and signs within a frame from:

i. Social distance where the depicted person is closer to us via close-up shot or far from us through medium close-up or long shot.

ii. Social relation where the depicted person's involvement from frontal or detachment from oblique angle from us the viewers. While at eye level, the depicted person has equal power relationship with viewers. At high level, viewers hold the power over depicted person and at low angle, it is otherwise.

iii. Social interaction with direct address (the depicted person looks) and indirect address (the depicted person does not look) at the viewer.

The analysis of social distance, relation and interaction on the position of Tun Dr Mahathir with other actors can contribute with sentiments visually from a social perspective as to how viewers perceive the images and signs to represent in regards to pre-election sentiments.

Compositional meaning making may take place via framing and salience of images or signs. The composition depends on the way images or signs interacted visually through collective scattered and communicated events of micro elements. The scattered events can either be visually connected or disconnected by direct or indirect interpretations of a specific discourse. However, it is the salience in foregrounding of discourses at micro level that contributes towards a macro level conceptual roadmap to be traced of a particular topic in question. Nevertheless, signs or symbolic meanings could be made meaningfully through different forms of reading (Hall, 2006) by its viewers. Different forms of readings allow viewers to encode and decode a short film.

Finally, we employ Hall's (2006) reception theory to analyse the readings which can be dominant, negotiated or oppositional in the way messages are conveyed in order to achieve a particular goal. According to Hall (2006), images and signs decoded towards dominant reading leave the message without any questioning. Therefore, the images and signs are visually accepted without any form of argument or it is accepted as that is what the signs mean. As such, that is what all others accept with the knowledge of that particular culture the signs intend to signify. Through negotiated reading, some parts of the messages can be accepted or rejected. However, through oppositional reading, every part of the message is not accepted (Hall, 2006) or in some cases, the oppositional message could bring along oppositional ideas.

The symbolic meanings of images and signs can also represent time. Hence, we also adopt van Leeuwen's (2008) timing network to examine how Tun Dr Mahathir is represented through discursive structures of different readings of timing. Time is a product measuring an 
activity, sequent or event with that of another sequence of activity or event (Elias \& Jephcott, 1992). In such circumstances, time is a product depending on how we think and talk about certain happenings, be it at present, past or in the future. Hence, time can be historically confined with political signification with symbolic values of the past, present and future. However, it all depends on viewers' perception communicated with knowledge that culturally connotes with present social or political place of origin (van Leeuwen, 2008).

In our analysis of the short film, location (time summons) and extent (social synchronisation) are the fundamental types of timing (van Leeuwen, 2008). There are three categories of time summons: personalised, instrumentalised and disembodied.

- Personalised usually occurs in institutions, workplace or educational institution where someone is given the right to authoritatively time the activities of another participant. It can also be represented non-verbally through gestures or gaze.

- Instrumentalised is where one summons time through an instrument such as alarm clock, whistle, traffic lights or bell in school.

- Disembodied is where time is summoned through internalised sense of timing such as knowledge or culture.

On the other hand, extent with synchronisation is timing by reference to successive order of events in some other change continuum (Elias \& Jephcott, 1992). The change continuum can be of various social activities through education, family, and institution synchronisation that connotes with or suggests natural order or realistic happenings. Specifically, our focus is on social and political synchronisation where time activity is valued with much sense to pre-election sentiments synchronised with Tun Dr Mahathir with various social timings, visually communicated via the short film, HARAPAN.

\section{ANALYSIS: ROADMAPS WITH TIMING}

Through the signification of images and signs, the twenty identified still frames give way to five dominant conceptual roadmaps. The frames that give way to the roadmaps were scattered among the twenty frames with different time summons in the representation of Tun Dr Mahathir. Hence, the identification of the roadmaps does not follow in accordance to the narrative flow of still frames as in Figure 1. Instead, the frames are fragments out of the twenty frames of which each roadmap relates to Tun Dr Mahathir with political and social time summons. The identified five conceptual roadmaps and the total number of fragmented still frames are shown in Table 1.

TABLE 1. Conceptual Roadmaps and Frames

\begin{tabular}{llc}
\hline Conceptual roadmaps & Coded frames & Total frames \\
\hline Father of modernisation & $1,5,7,8,9,10,11,12$ and 13 & Nine \\
Popular prime minister across society & $2,3,4,6,19$ & Five \\
Political twist & 14 & One \\
Return of a political icon & $15,16,17,18$ & Four \\
Political symbol of hope & 20 & One \\
\hline
\end{tabular}




\section{FATHER OF MODERNISATION}

The first roadmap comprises a total of nine frames as shown in Figure 3.
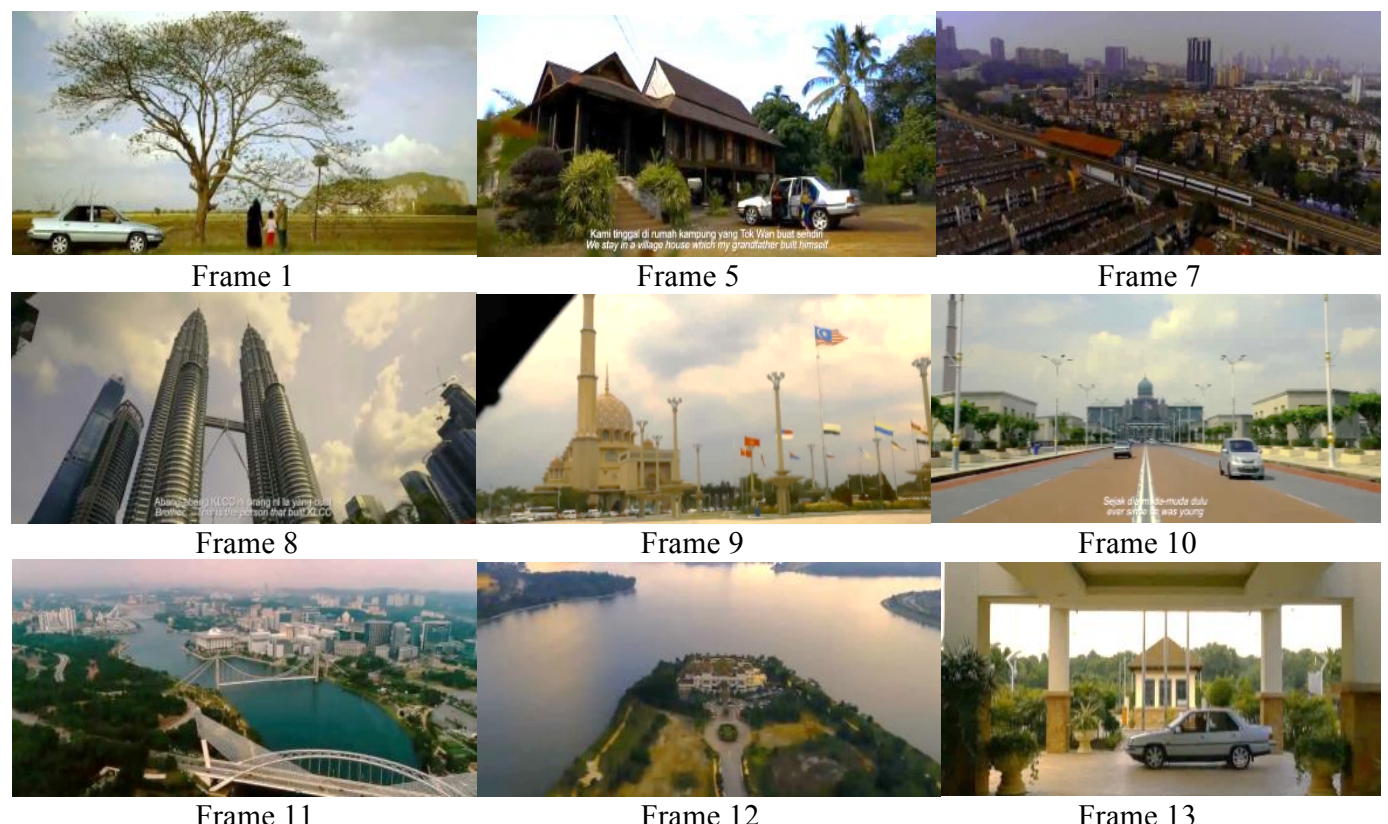

FIGURE 3. Father of modernisation

The image in Frame 1 shows Aisyah facing the paddy field with her grandparents. There is a tree and a car nearby. In Frame 5, Aisyah arrives at her grandparents' home which is a Kedah village house. The images of Frame 7 and Frame 8 show the development in Kuala Lumpur while Frame 9 to Frame 13 in Putrajaya. The images in the nine frames from a social distance consist of long shots that are far away from the viewers' angle. However, the long shot of images in all nine frames at the same time indirectly reflect upon Tun Dr Mahatir's past initiated developments in mondernising Malaysia during his twenty-two years as the prime minister of Malaysia. Hence, from a social distance, the frames in Figure 3 closely reflect upon Tun Dr Mahathir from a social and political aspect to the viewers. For example, the images of paddy field in Frame 1 and the Kedah house in Frame 5 historically signify the place of his origin, the state of Kedah. Kedah is also where Tun Dr Mahathir started his political career in his younger days. Besides, the indirect involvement could bring about the social interaction of Tun Dr Mahathir of his political achievements in developing and modernising Malaysia. Moreover, he is honoured with the title 'Father of Modernisation' from historical and educational perspectives to Malaysians of all ages. The representation through the far long shots of all nine frames meaningfully signifies Tun Dr Mahathir's past reign as prime minister.

The images in Frame 1, Frame 5, Frame 10 and Frame 13 show Aisyah and her grandparents travelling in Proton Saga, a car initiated to be locally assembled by Tun Dr Mahathir. Hence, via the image of the car, time summon of Tun Dr Mahathir's political and historical pasts are imposed and instrumentalised with symbolic meaning of his achievements while in office as prime minister. The images of Frame 7 to Frame 13 directly address the public transportation system (Frame 7) and twin towers (Frame 8) in Kuala Lumpur, the mosque 
(Frame 9), prime minister's office (Frame 10), the highways (Frame 11) and prime minister's art gallery (Frame 12 and Frame 13) in Putrajaya.

The graduation and multiple combinations of these frames with dominant and prominent images of development and modernisation may consciously or unconsciously from viewers' perspective connote with Tun Dr Mahathir's past achievements. In Frame 10, there are images of two cars on the road initiated by Tun Dr Mahathir: Proton Saga and Perodua MyVi. The image of Proton Saga is on the left and Perodua MyVi is on the right. Additionally, the white double lines on the road separate the cars as the lines indicate no overtaking. Both cars visually and indirectly represent Tun Dr Mahathir with his past progressive achievements in the local car industry. Subsequently, the cars are instrumentalised with time summons of the past political achievement and the present political environment involving Tun Dr Mahathir.

The power of timing through the images of the car therefore may visually bring to the realisation the process of his past success to the viewers. In Frame 13, the image of Proton Saga appears as Aisyah arrives at the prime minister's art gallery. The art gallery at Putrajaya is also historically symbolic to Tun Dr Mahathir's political achievement during his past political carrier.

Time summons of the past are represented as being imposed through images and signs negotiated via timing which are dominant in terms of location and extent. Through location, the cars, house, and developments are symbolically instrumentalised with Tun Dr Mahathir. The presence of Aisyah with her grandparents and the activity of their travelling are socially synchronised with the political status of Tun Dr Mahathir's past achievements across two generations: the grandparents and granddaughter. Connotatively, the nine frames dominantly depict Tun Dr Mahathir's past political achievements which symbolically reflect upon his status as the Father of Modernisation while serving as the $4^{\text {th }}$ Prime Minister of Malaysia.

\section{POPULAR PRIME MINISTER ACROSS SOCIETY}

The images in Frame 2, 3, 4, 6 and 19 in Figure 4 consist of various ideas at different levels of society. All the five frames with still images and signs are analysed in consideration to the representation of Tun Dr Mahathir across society.

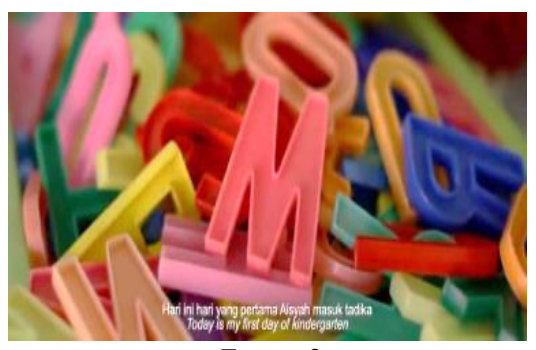

Frame 2

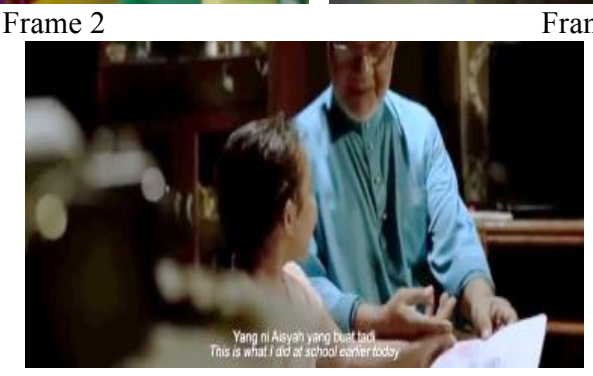

Frame 6

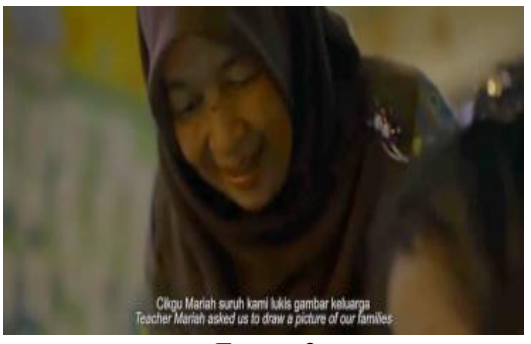

Frame 3

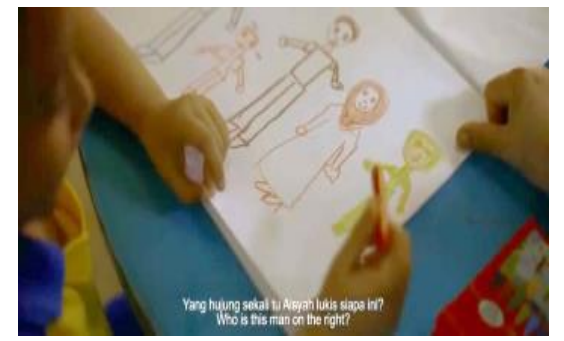

Frame 4

FIGURE 4. Popular prime minister across society 
Unlike Frame 3, 4, 6 and 19, Frame 2 does not have an image of a person or of that of a person (drawing). However, it does not mean Frame 2 has no depiction of a person or persons across society such as a teacher, a student or a family member. The images of Frame 2 are mixed letters of the English alphabet use for learning at school by children in kindergarten such as Aisyah. Among the colourful letters, ' $\mathrm{M}$ ' is dominant as it is in its complete form compared to the other letters. ' $M$ ' is elevated as it is above all other letters and is directly involved with the viewers from a frontal angle. In this short film, the letter ' $M$ ' may symbolise Tun Dr Mahathir or represent Malaysia. However, the image of a teacher from a close and an oblique angle attending to Aisyah leads to the function of the image with meaning associated with Tun Dr Mahathir. In Aisyah's drawing, Tun Dr Mahathir's figure is dominant compared to other figures of her family members as he is the only one who is fully coloured (Frame 4). In Frame 3, the teacher smiles pleasantly while looking at Aisyah's drawing. In Frame 6, Aisyah returns home to her grandfather and shows him the drawing and relates it to the picture of Tun Dr Mahathir (Frame 19). The grandfather is involved with his grandchild's interest; he smiles and listens without any form of objection. The portrait of Tun Dr Mahathir on the wall is elevated from Aisyah and her grandfather's angle. At the same time, Tun Dr Mahathir's image with a smile and gaze relates him directly when compared to Aisyah and her grandfather who are seated and not in direct address from viewers' angle. From the images and signs of the five frames, Tun Dr Mahathir is salient through the composition of time summons via dominant readings of location with social synchronisation. Firstly, in Frame 2, the letter ' $M$ ' is in a way instrumentalised to depict the $4^{\text {th }}$ Prime Minister of Malaysia that is Tun Dr Mahathir. Hence, the letter ' $M$ ' indirectly represents Mahathir as the first initial of his name rather than the country where he served as prime minister. Secondly, the teacher and Aisyah's depiction at school as an institution of education is perceived with political ties and social synchronisation of timing.

The teacher, Aisyah, her grandparents and the letters are seemingly instrumentalised with the present location of time summons in the depiction of Tun Dr Mahathir. He is represented through the composition of the five frames into the idea of being idolised and remembered by not only the young generation, but also by the teacher at school and the grandfather at home. Tun Dr Mahathir is depicted with social involvement at different societal levels with his social relation in different locations and timings. The timing is located in the past as Tun Dr Mahathir is seen as a young prime minister. Through the narrative of Aisyah, her grandparents and teacher, Tun Dr Mahathir is symbolically represented as not forgotten neither by the young or the old. Neither is he forgotten by the education system. Hence, he is depicted as socially idolised at various levels of society through Frame 2, 3, 4, 6 and 19, symbolically signify a conceptual roadmap negotiated between the past and present as a political idol accepted across different generations. Thus, Tun Dr Mahathir is represented as popular across society.

\section{POLITICAL TWIST}

Figure 5 shows only one frame that is Frame 14. This frame consists of a long shot that establishes Aisyah's entrance into the prime ministers' art gallery with her family. 


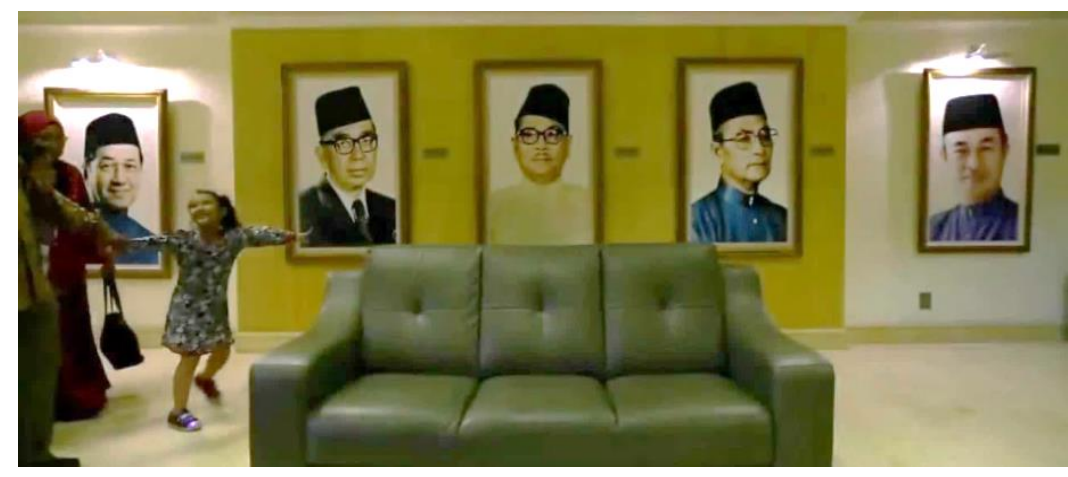

Frame 14

FIGURE 5. Political twist

There are portraits of five Malaysian prime ministers. Tun Dr Mahathir's portrait is on the left, followed by Tun Razak. Tun Razak is the $3^{\text {rd }}$ Prime Minister of Malaysia. He is also the father of Najib Razak. In the middle is the portrait of the $1^{\text {st }}$ prime minister and next to him is the $2^{\text {nd }}$ and followed by the $5^{\text {th }}$ Prime Minister of Malaysia.

Aisyah's family is not directly in close involvement with viewers as they are at far distance and an oblique angle in comparison with Aisyah who holds power over her representation. Although she does not look directly at viewers with her gaze, through social interaction, she gains attention with her action. She points at one of the portraits and at the same time draws viewers' attention and critiques of her action as well as the portraits. Nevertheless, an empty couch is of close distance with viewers from a frontal angle. The couch can be indirectly involved in the representation of prime ministers from viewers' angle.

The dominance of the prime ministers' portraits within the art gallery lined-up from left to right through the narrative of Frame 14 in a way suggests the regime of the $1^{\text {st }}$ till the $5^{\text {th }}$ Prime Minister of Malaysia. At the time of filming of this short film, Najib Razak who is the $6^{\text {th }}$ Prime Minister of Malaysia is not visually presented. The absence of Najib Razak's portrait opens for critique (van Leeuwen, 2008) as the distancing strategy via the portrait of the $6^{\text {th }}$ prime minister may unconsciously allow viewers to exclude him in the line of those who have served the country. In other words, via the dominant reading of the portraits, there may be a symbolical and political twist signifying oppositional reading, subtly towards Najib Razak rather than Tun Dr Mahathir (Hall, 2006). Besides, the entrance of Aisyah and her family from viewers' angle are symbolically in close distance and involvement as they stand in front of Tun Dr Mahathir's portrait before Aisyah leads them to the portraits of the other four prime ministers. Hence, in Frame 14, the social interaction within a single long shot (Frame 14) through images of Aisyah and her family along with the portraits of the five prime ministers may give way to more prominence to Tun Dr Mahathir compared with other reigned prime ministers and the present reigning prime minister.

Interestingly, timing is also negotiated through Aisyah's visit with her family to the art gallery built by Tun Dr Mahathir. The visual designed agency provided through the scene of the art gallery may represent the location of time summons negotiated with Tun Dr Mahathir and his political election campaign in Malaysia. Echoing with the ongoing political crisis, Tun Dr Mahathir at present is a returning candidate against Najib Razak to be the next prime minister in the $14^{\text {th }}$ Malaysian general election. Nevertheless, the empty couch in Frame 14 could also be instrumentalised with time summons presumably to personalise Tun Dr Mahathir from viewers' 
perspective to fill the seat of the next prime minister. The unfilled seat could also be timely to represent the dissolved parliament (at the time the short film was broadcast) with an empty prime minister's seat waiting to be fulfilled by the nation's choice. Hence, the processes of instrumentalisation of the couch and portraits along with the location of the art gallery as in Frame 14 may visually represent the continuum of changes of historical and political twist that may prompt viewers', perception with the conceptual leaps (MacDougall, 2005) of timing with past and present time summons of the $14^{\text {th }}$ Malaysian general election campaign. Frame 14 may also explicitly establish Tun Dr Mahathir's political struggles to return to politics at the age of 93 after having been a prime minister for twenty-two years and in opposition with BN party which he had formerly served. Overall, Tun Dr Mahathir is visually depicted with a twist in this single frame. The twist is in his political career and as a prime minister in line with the BN leaders who are all from the same party he had served in the past.

\section{RETURN OF A POLITICAL ICON}

A total of four frames formed the conceptual roadmap on Tun Dr Mahathir through Aisyah at the art gallery. The four frames (i.e. Frame 15 to Frame 18) shown in Figure 6 are not scattered but are linked in sequence as in the short film.

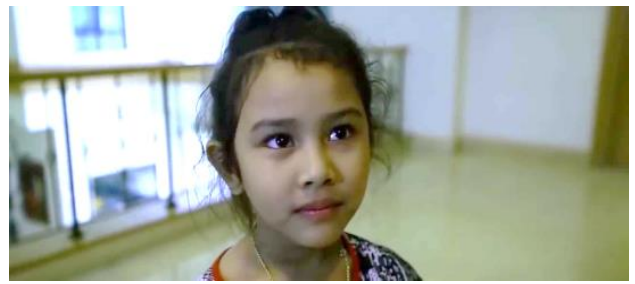

Frame 15

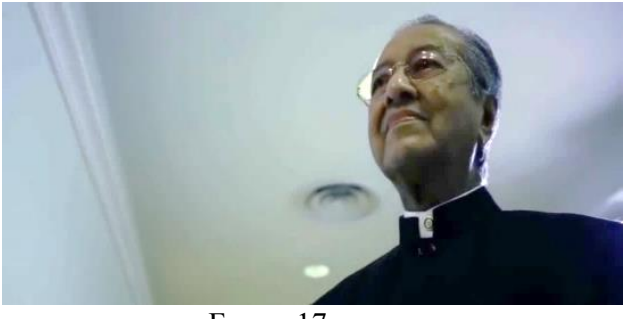

Frame 17

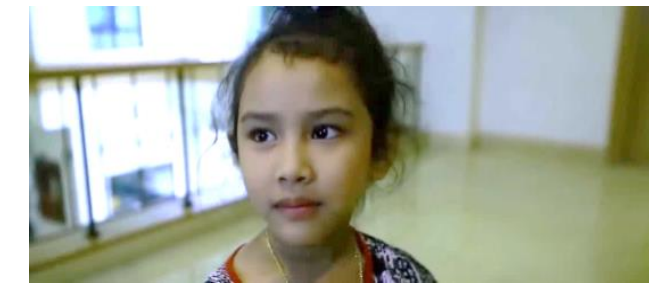

Frame 16

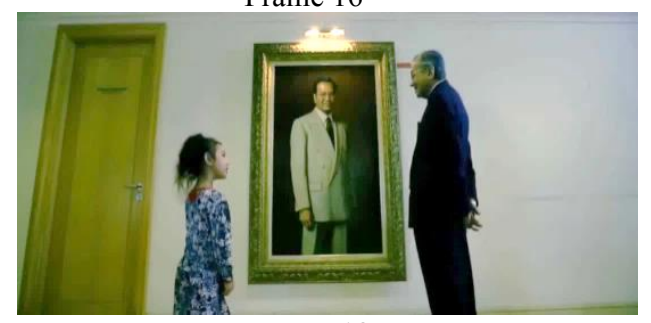

Frame 18

FIGURE 6. Return of a political icon

In Frame 15, Aisyah is looking at Tun Dr Mahathir's portrait. Her image is at close angle with viewers while she gazes from an oblique angle from the viewers. Yet, Aisyah holds power over her representation as "one of us" (van Leeuwen, 2008, p. 138) through her gaze. Via her gaze, she summons the viewers to the location she is deeply engrossed with, that is the portrait of Tun Dr Mahathir at the art gallery (Frame 18).

As she turns and fixes her gaze in Frame 16, Tun Dr Mahathir stands before her. He is elevated through Aisyah's gaze. In other words, Tun Dr Mahathir holds power to his representation compared to Aisyah who depicts the younger generation but not Tun Dr Mahathir who stands as the Prime Minister of Malaysia and the person Aisyah admires. In Frame 18, Tun Dr Mahathir stands face to face with Aisyah as he faces away from the viewers from an oblique far angle within the frame. At the same time, between the image of the girl and the politician is 
the portrait of Tun Dr Mahathir in his younger version as a prime minister. His gaze in the portrait is with direct address with viewers from a frontal angle. The image of the portrait is also elevated. Thus, the portrait depicts Tun Dr Mahathir's involvement as the prime minister during his reign with honour. Interestingly, the image of him in the portrait and with him face to face with Aisyah overlaps with the younger and older version of Tun Dr Mahathir in the past and with present historical moment in time of his political struggle to be the next prime minister. The idea between images in the four frames (Frame 15 to Frame 18) provides a powerful representation of Tun Dr Mahathir's past and present historical political reflections.

Aisyah's gaze negotiates admiration of the young generation on Tun Dr Mahathir as an icon of the past and at the age of 93 with his return to be the next Prime Minister of Malaysia. Moreover, Tun Dr Mahathir's outfit at present time made popular to Malaysians during his twenty-two years of regime. His location in two different timings allows viewers to make comparison of him to be depicted as a known past political figure and as a man who is known to return and stands before the people. On the other hand, the image of closed door in Frame 18 from a far angle in the presence of Aisyah, the portrait and Tun Dr Mahathir can symbolise the door that can be opened for a new hope and better future for Malaysians. In other words, the closed door is negotiated to the significance of a hope to the election of the next prime minister in the upcoming $14^{\text {th }}$ general election. Besides, in comparison to Frame 14 in Figure 5, only Tun Dr Mahathir's portrait is highlighted in Frame 18 with his political power sentiments hence focusing on him rather than any other prime ministers before or after his reign.

Timing can be syncronised through the young girl's gaze of a past icon in the present, admired and remembered and yet in the future as a candidate to be the next prime minster of Malaysia. Timing is also negotiated via the dominant discourses of Tun Dr Mahathir's social and political positioning through his portrait, outfit and the closed door with Aisyah in the gallery (Frame 18). Visually, Tun Dr Mahathir is personalised via his presence be it in real or through his image in the portrait. The door, his portrait and his positioning face to face with the girl are instrumentalised through disembodied timing that locates his various levels of political positioning. The positioning politically represents his present struggles to justify his return as an icon, previously admired by Malaysians.

\section{POLITICAL SYMBOL OF HOPE}

In Figure 7, Frame 20 shows the last frame that is seen at the end of the short film HARAPAN. This frame consists of a long shot with far distance from a frontal angle of a vast land with two words. The word HARAPAN in upper case font and in Malay language appears in the centre of the frame. Below the word HARAPAN, in lower case fonts appears the word hope in italics.

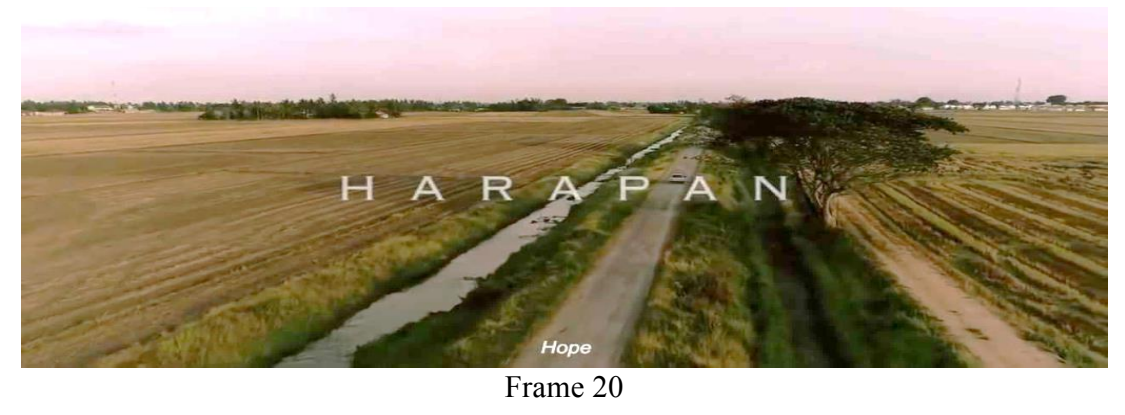

FIGURE 7. Political symbol of hope 
This frame also shows the end of Aisyah's journey back to her village in the state of Kedah. She travels in her grandfather's Proton Saga, the first version of this car introduced in Malaysia. Both sides of the frame are vast land of paddy fields ploughed and dry. In the middle of the land is a long road along with a river next to it leading to the village. The Proton Saga is on its way towards the village where Aisyah derives from. Unlike the dry land, the paddy field next to the road and along the river is fresh and fertile with the tree that Aisyah stood with her grandparents at the beginning of this short film (Frame 1). The end of this short film in this single frame is signified with the word HARAPAN (hope), flashed at eye angle with viewers.

The images within Frame 20 of the paddy fields on both sides of the road leading to where Aisyah comes from visually depicts the state of Kedah as this state is known as the rice bowl of Malaysia. Additionally, this is the same state where Tun Dr Mahathir originates from. Hence, Tun Dr Mahathir is indirectly and connotatively addressed in this frame vis-à-vis with the Proton Saga on the road, the vast paddy land and the tree which still stands on green grass.

The state of dried land may connotatively indicate the present situation with financial or economic crisis socially encountered by Malaysians during the ruling of Najib Razak. The presence of the tree against the dried land and a small stream along the road may represent the possibility for a choice of a fresh growth socially and politically towards a better future in the upcoming election. As such, the stream and tree may indirectly signify the social relations and involvement of Tun Dr Mahathir as a choice of the next prime minister for political growth who with his historical and popular origin tied to the state of Kedah. The green grass may also represent growth to the land of Kedah or the Malaysian society with a fruitful hope through the return of Tun Dr Mahathir to politics.

The presence of Proton Saga leading back to the township signified via the zooming out of the word HARAPAN (hope). Frame 20 provides overlapping representations through salient images with the composition of symbolic social and political crisis that interact with pre-election sentiments. The sentiments may depict with perceptions that come with the choice of hope. The hope is socially associated with time summons via the images which are instrumentalised towards Tun Dr Mahathir for a fresh start with the upcoming election. Visually, messages are symbolically signified via the images for a better future. However, the choice is indirectly imposed between Tun Dr Mahathir and Najib Razak. Moreover, the zooming of the word HARAPAN can symbolise Pakatan Harapan, the opposition party formed by Tun Dr Mahathir to win against Najib Razak in the upcoming elections. The zooming of the title of the short film can also visually disembody Tun Dr Mahathir as an instrument of hope for a change of regime and thus a better future. However, the choice is upon viewers who represent the people of Malaysia to come with the hope for a change as well as Tun Dr Mahathir as the hope to once again be the next Prime Minister of Malaysia.

\section{VISUAL REPRESENTATION}

Visually, various ideas in the short film connote Tun Dr Mahathir with political project via specific historical and social experiences and discursive conditions (Lopez \& Weinstein, 2012) with Malaysian pre-election politics from viewers' social perspective. We also found centrality to the shaping of collective perceptions through the dynamics of representation of not only via dominant reading, but with symbolic relations through negotiated and oppositional readings based on different timings. Our visual analysis across the twenty frames represents Tun Dr 
Mahathir with various conceptual discourses in the form of three different dominant readings of time with political aims. The discourses are socially associated with timings of the past, present and future with a political message of hope to viewers. Primarily, through the eyes of Aisyah the little girl, Tun Dr Mahathir's past contributions are negotiated across two different generations. The generations are socially represented across society, both young and old. He is visually and historically negotiated with memories of his past political achievements with the notion of being honoured as the Father of Modernisation. The honour in favour of him is for the development he had brought to the country while serving as a prime minister for twenty-two years. Visually, his depiction is not oppositional to the country or the nation with the upcoming election. Instead, he is seen idolised as a successful icon of the country remembered by the people as a prime minister with his past contributions to both the country and society. He is not forgotten as his portrait hangs not only at the art gallery but also at homes of Malaysians. He is also honoured and remembered at school as well as by the education system that encourages his past historical deeds as the one who developed the nation. Hence, he is visualised as the most popular and idolised prime minister by the society at all levels compared to all other Prime Ministers of Malaysia.

Interestingly, Tun Dr Mahathir is socially visible (Martin-Barberro, 2006) as a hero figure compared to those prime ministers who had served before or after him without much space for argument. The discourse visually demonstrates in favour of Tun Dr Mahathir not to critique but to honour and favour him. Additionally, the past and present visual depictions of him negotiate his return to politics as an icon with a symbol of hope. Yet, the dominant readings visually in favour of Tun Dr Mahathir came along with oppositional readings with pre-election sentiments.

All prime ministers before and after Tun Dr Mahathir of their successions is negotiated indirectly through the portraits that hang at the art gallery. The present regime under Najib Razak at time HARAPAN was broadcast visually gives way to critique. The absence of Najib Razak's portrait via HARAPAN therefore brings a political twist where Tun Dr Mahathir's social dominance connotes with oppositional sentiments to his return to politics. The visually negotiated twist consciously or unconsciously provokes political sentiments not only across society through the frames of the film, but also includes viewers as one of 'us'. Thus, the film HARAPAN through its images and signs symbolically demands 'us' (Malaysians) to fulfil the seat of the next Prime Minister of Malaysia. Hence, the agency given visually towards Tun Dr Mahathir through various narratives of Aisyah at different phases includes the 'us' as the subjects of the political struggle by Tun Dr Mahathir to bring a change in Malaysia. The change is a hope via a call that communicates the viewers through dominant and negotiated readings of the past and present along with a change of regime for the future in the $14^{\text {th }}$ general election. Such a call interplays with phases of time.

\section{CONCLUSION}

Visually, the short film disembodies different political roadmaps of timing which represents Tun Dr Mahathir as an instrument to make the hope into reality towards a better future. Interestingly, as an instrument, he is visually designed with discursive conditions of historical and social experiences undergone by the Malaysian society (Lopez \& Weinstein, 2012). Evidently, different political roadmaps of timing represent him as an instrument to make the hope to be a reality. The 
reality is for a better future that visually compares him to the regime of Najib Razak and social struggle for a change with ruling government.

Interestingly, images and signs of the short film grammatically reach across the Malaysian society of all walks of life. The narrative is socially represented through the sentiments of those who will be voters of the $14^{\text {th }}$ general elections as well as viewers of HARAPAN who are non-voters but the future generation. Visually, he is represented as the iconic political symbol to be cherished by the young generation that were not even born during his regime. Such a short film is indeed detailed with its selection of images and signs that socially uplift his devotion to the country, people and the nation.

Remarkably, the short film visually represents Tun Dr Mahathir with long term political objectives. The objectives are visually directed to leave behind memories of his past success and his hope for a country with a vision and at the same time as an iconic figure even after the present existing generation. This study is timely as Tun Dr Mahathir successfully achieved his political objectives via his short film broadcast. He has been the choice of hope to the Malaysian society as he leads Malaysia with Pakatan Harapan, a political party itself of which he joined.

Furthermore, when compared to earlier studies undertaken by Khoo (2008), Izharuddin (2015), Sora (2010), Coëgnaerts and Kravanja (2012) or A Rethina Velu and Kaur (2018a, 2018b), findings of this study yield different results. None of their studies adopted three different frameworks to provide a single component framework. As such, our theoretical foundation provides insight to an in-depth holistic approach to visual analysis from a multimodal discursive perspective from not only the images within a frame, but also the interaction of images from frame to frame throughout the short film. Nevertheless, this short film also offers insights towards the manipulation of timing via roadmaps with impact not only with the present voters, but also towards the future generations who would one day be future voters of their country.

In conclusion, the five roadmaps are filled with recreated memories familiar with the understanding of reality (Martin-Barberro, 2006) where the film narrative is a struggle with symbolic political meanings both by Tun Dr Mahathir and the Malaysian society. Through this study, discourse analysts may benefit from a systematic analysis that involves conceptual roadmaps through film narratives of a particular discourse in question of a various levels that involves timing. Hopefully, this study contributes to our understanding of visual symbolisms out of still frames that contribute from micro to macro narratives. Different short films may yield different results depending on the discourse being analysed overlapped with ideas that project the past, present and future. A useful recommendation for future research would be to conduct further study on other short films by applying synchronised time summons with cinematic representations through analysis of verbal texts or movement within frames and from frame to frame. Further study should also examine why the short film HARAPAN mainly highlights on one ethnicity when Malaysia is a multiracial country in regards to historical and social discursive conditions.

\section{REFERENCES}

A Rethina Velu, U. R. \& Kaur, S. (2018a). Mirroring men in society: Dynamics of images of the "self" and "other" in a Malaysian televised show. Journal of Language \& Communication. Vol. 5(1), 29-45.

A Rethina Velu, U. R. \& Kaur, S. (2018b). Convergence of visual interpretation through collective practices of masculinity in a Malaysian televised show. The Journal of South East Asia Research Centre for Communication and Humanities. Vol. 10(2), 115-136.

Abas, N., \& Kaur, S. (2019). Theologising the discourse of representation through 'faith' and religion in football news. 3L: Language, Linguistics, Literature. Vol. 25(3), 150-162. 
Berger, J. (1972). Ways of Seeing. Harmondsworth, England: Penguin.

Bezemer, J. \& Kress, G. (2008). Writing in multimodal texts: A social semiotic account of designs for learning. Written Communication. Vol. 25(2), 166-195.

Coëgnaerts, M., \& Kravanja, P. (2012). The visual and multimodal representation of time in film, or: How time is metaphorically shaped in space. Image and Narrative Online Magazine of the Visual Narrative. Vol. 13(3), $85-100$.

Elias, N. \& Jephcott, E. (1992). Time: An Essay. Oxford: Blackwell.

Gee, J. (2018). Mahathir is opposition candidate for Malaysian prime minister-officially, at least. The Washington Report on Middle East Affairs. Vol. 37(2), 47-48.

Hall, S. (2006). Encoding/decoding. In Meenaksi, G. D. \& Douglas, M. K. (Eds.). Media and Cultural Studies (pp. 163-173). UK: Blackwell Publishing.

Harapan. (2018). video recording, YouTube, viewed 1 December 2018, <https://www.youtube.com/watch?v= YWmCAWhBM3I\& $\mathrm{t}=5 \mathrm{~s}>$.

Izharuddin, A. (2015). The short films of Mien Ly and an articulation of feminist queer theory in Malaysia. Intersections-Gender and Sexuality in Asia and the Pacific, 38, 1-13.

Khoo, G. C. (2008). Urban geography as pretext: Sociocultural landscapes of Kuala Lumpur in independent Malaysian films. Singapore Journal of Tropical Geography, 29(1), 34-54.

Kress, G. (2004). Reading images: Multimodality, representation and new media. Information Design Journal. Vol. 12(2), 110-119.

Kress, G. \& van Leeuwen, T. (2006) Reading Images: The Grammar of Visual Design. London: Routledge.

Lemiere, S. (2018). The downfall of Malaysia's ruling party. Journal of Democracy. Vol. 29(4), 114-128.

Lopez, A. R. \& Weinstein, B. (2012). The Making of the Middle Class: Toward a Transnational History. Durham, NC: Duke University Press.

MacDougall, D. (2005). The Corporeal Image: Film, Ethnography, and The Senses. New Jersey: Princeton University Press.

Martin-Barberro, J. (2006). The processes: From nationalisms to transnationalisms. In Meenaksi, G. D. \& Douglas, M. K. (Eds.). Media and Cultural Studies (pp. 626-657). UK: Blackwell Publishing.

Milne, R. S. \& Mauzy, D. K. (2002). Malaysian Politics under Mahathir. New York: Routledge.

Mulvey, L. (1975). Visual pleasure and narrative cinema. Screen. Vol. 16(3), 6-18.

Ng, N. M. A. \& Zainal Amin Ayub. (2018). The illicit enrichment law and financial disclosure system in Malaysia. International Journal. Vol. 3(13), 331-341.

Perry, M. S. (2018). 21st century skills through film production in tertiary education: A transformative assessment in a literature and media course. 3L: Language, Linguistics, Literature. Vol. 24(4), 214-232.

Song, M. Y. \& Sivachandralingam Sundara Raja. (2018). Malaysia-south Korea economic relations: Mahathir Mohamad made the difference. Sejarah: Journal of the Department of History. Vol. 27(1), 111-134.

Sora, C. (2010). The phenomenology of time in interactive visual representations. Singapore Journal of Tropical Geography. Vol. 29(1), 34-54.

Ting, H. (2009). The politics of national identity in West Malaysia: Continue mutation or critical transition? Japanese Journal of Southeast Asian Studies. Vol. 47(1), 31-51.

van Leeuwen, T. (2008). Discourse and Practice: New Tools for Critical Discourse Analysis. Oxford: Oxford University Press.

Vega, R. (2018). Watch Mahathir's latest heartfelt video that's touching Malaysian's hearts. Available at: https://www.worldofbuzz.com/watch-mahathirs-latest-heartfelt-video-thats-touching-malaysians-hearts/ (accessed 1 December 2018).

Vijayan P. Munusamy. (2012). Ethnic relations in Malaysia: The need for "constant repair" in the spirit of Muhibbah. In Landis, D. \& Albert, R. S. (Eds.). Handbook of Ethnic Conflict: International Perspective (pp. 119-136). New York: Springer.

Walid Jumblatt Abdullah. (2018). The Mahathir effect in Malaysia's 2018 election: The role of credible personalities in regime transitions. Democratization. Vol. 26(3), 1-16. 